\title{
Dynorphin Opioid Peptides Enhance Acid-Sensing Ion Channel 1a Activity and Acidosis-Induced Neuronal Death
}

\author{
Thomas W. Sherwood and Candice C. Askwith \\ Department of Neuroscience, The Ohio State University, Columbus, Ohio 43210
}

Acid-sensing ion channel 1a (ASIC1a) promotes neuronal damage during pathological acidosis. ASIC1a undergoes a process called steady-state desensitization in which incremental $\mathrm{pH}$ reductions desensitize the channel and prevent activation when the threshold for acid-dependent activation is reached. We find that dynorphin A and big dynorphin limit steady-state desensitization of ASIC1a and acid-activated currents in cortical neurons. Dynorphin potentiation of ASICla activity is independent of opioid or bradykinin receptor activation but is prevented in the presence of PcTx1, a peptide which is known to bind the extracellular domain of ASIC1a. This suggests that dynorphins interact directly with ASICla to enhance channel activity. Inducing steady-state desensitization prevents ASIC1amediated cell death during prolonged acidosis. This neuroprotection is abolished in the presence of dynorphins. Together, these results define ASIC1a as a new nonopioid target for dynorphin action and suggest that dynorphins enhance neuronal damage following ischemia by preventing steady-state desensitization of ASICla.

\section{Introduction}

The acid-sensing ion channels (ASICs) are a family of cation channels activated by acidic extracellular $\mathrm{pH}$ (Waldmann et al., 1997). ASICs are expressed in neurons and play roles in sensory transduction, learning, memory, fear, cardiovascular regulation, seizure termination, retinal function, and pain perception (Ettaiche et al., 2006; Wemmie et al., 2006; Duan et al., 2007; Mazzuca et al., 2007; Coryell et al., 2008; Drummond et al., 2008; Ziemann et al., 2008). There are four ASIC genes (ACCN1-4) that encode multiple ASIC subunits. The ASIC1a subunit plays a dominant role in the CNS and eliminating ASIC1a activity eliminates current evoked by $\mathrm{pH}$ values $>5.0$ in central neurons (Askwith et al., 2004). Inhibiting ASIC1a activity also limits neuronal death following experimental stroke in mice (Xiong et al., 2004). It is thought that the prolonged acidosis accompanying cerebral ischemia causes inappropriate activation of ASIC1a channels resulting in excess calcium accumulation and subsequent neuronal death (Xiong et al., 2007). Recently, ASICla has also been implicated in neuronal death in several neurodegenerative disorders, suggesting ASICla-mediated death might represent a common mechanism of neuronal loss in CNS disease (Friese et al., 2007; Arias et al., 2008; Wong et al., 2008).

ASICs activate in response to large and rapid reductions in $\mathrm{pH}$, while gradual incremental drops in $\mathrm{pH}$ prevent ASICla activation in a process known as steady-state desensitization (Babini

Received May 6, 2009; revised 0ct. 2, 2009; accepted 0ct. 10, 2009.

This work was funded by a Scientists Development Grant from the American Heart Association and National Institutes of Health Grant R01 to C.C.A., as well as an American Heart Predoctoral Student Fellowship to T.W.S. We thank W. Sadee and K. Mykytyn for helpful discussions and comments on this manuscript. We are grateful to $G$ Bishop for the use of the Axioscope microscope and to M. Welsh, J. Wemmie, and M. Price for supplying CDNA clones and transgenic animals.

Correspondence should be addressed to Candice C. Askwith, 4197 Graves Hall, 333 West 10th Avenue, Department of Neuroscience, The Ohio State University, Columbus, OH 43210. E-mail: Askwith.1@osu.edu.

D01:10.1523/JNEUROSCI.2186-09.2009

Copyright $\odot 2009$ Society for Neuroscience ～0270-6474/09/2914371-10\$15.00/0 et al., 2002). Desensitized channels fail to conduct substantial current even when the threshold for activation is reached. This may be particularly relevant in pathological conditions in which acidosis occurs over several minutes. In fact, PcTx1, a compound that enhances ASIC1a steady-state desensitization, is neuroprotective in mouse models of stroke (Escoubas et al., 2000; Xiong et al., 2004; Chen et al., 2005; Pignataro et al., 2007). This suggests that induction of ASIC1a steady-state desensitization may prevent acidosis-induced neuronal death.

Recently, we found that RFamide-related neuropeptides potentiate ASICla activity by preventing steady-state desensitization, a process in opposition to the action of PcTx1 (Sherwood and Askwith, 2008). We found that the synthetic peptide FRRFamide, but not FMRFamide, prevented steady-state desensitization of mouse ASIC1a. In an effort to identify endogenous neuropeptides that modulate steady-state desensitization of ASIC1a, we looked to dynorphins. The dynorphin opioid peptides are among the most basic neuropeptides and are abundantly expressed in the CNS, including locations with high levels of ASIC1a such as the spinal cord, striatum, hippocampus, amygdala, and cerebral cortex (Wemmie et al., 2003; Hauser et al., 2005). In this study, we tested the effect of dynorphins on ASIC activity and determined that specific dynorphin peptides enhance ASIC1a current and acidosisinduced neuronal death.

\section{Materials and Methods}

Recombinant DNA expression in Xenopus oocytes. Unfertilized oocytes were harvested from female Xenopus laevis purchased from Xenopus-I, using standard procedures (Sherwood and Askwith, 2008). One to three hours after isolation, oocyte nuclei were injected with the pMT3 expression plasmid containing mouse ASIC cDNA at a $100 \mathrm{ng} / \mu \mathrm{l}$ concentration using a PV820 Pneumatic Picopump (World Precision Instruments). Oocytes were incubated at $18^{\circ} \mathrm{C}$ for $18-72 \mathrm{~h}$ before experiments were performed. 
Two-electrode voltage clamp on Xenopus oocytes. Whole-cell macroscopic current was measured using the two-electrode voltageclamp technique at a holding potential of -60 $\mathrm{mV}$. Electrodes $(\sim 2 \mathrm{M} \Omega)$ were pulled using a Sutter P-97 micropipette puller (Sutter Instrument) and filled with $3 \mathrm{M} \mathrm{KCl}$. Data were acquired using an Oocyte Clamp OC-725 Amplifier (Warner Instruments), an AXON Digidata 1200 digitizer, and pCLAMP-8 software (Molecular Devices). All experiments were done using frog Ringer's solution containing the following (in $\mathrm{mm}$ ): $116 \mathrm{NaCl}, 2 \mathrm{KCl}, 5$ HEPES, $5 \mathrm{MES}, 2 \mathrm{CaCl}_{2}, 1 \mathrm{MgCl}_{2}$ with a $\mathrm{pH}$ adjusted to the indicated levels using $1 \mathrm{~N}$ $\mathrm{NaOH}$. Oocyte recordings were done in a modified RC-Z3 $250 \mu$ l oocyte recording chamber (Warner Instruments). The solution exchange rate in the recording chamber was $\sim 1 \mathrm{ml} / \mathrm{s}$. ASIC current properties ( $\mathrm{pH}$-dependent activation and steady-state desensitization) were assessed as previously described (Sherwood and Askwith, 2008). ASIC current in experimental conditions was always flanked by saturating $\mathrm{pH}$ applications $(\mathrm{pH} 5.0$ unless otherwise noted) for comparison with maximal ASIC current. For quantification, peak current amplitude in experimental conditions was normalized to the average of the flanking maximal current amplitudes to minimize the impact of potential tachyphylaxis of protongated current. Neuropeptides were purchased from Phoenix Pharmaceuticals or synthesized by EZBiolab. Purified PcTx1 was purchased from Peptides International. B9430 was purchased from American Peptide.

Statistical analysis. Data were analyzed using the Axon Clampfit 9.0 software. To measure the rate of channel desensitization, the decay phase of current was fitted to the following single-exponential equation: $I=k_{0}+k_{1} \cdot e^{-t / \tau d}$, and the tau of inactivation $\left(\tau_{\text {inact }}\right)$ was calculated. $\mathrm{The}_{0.5} \mathrm{pH}_{0 .}$ walculated by fitting the data from individual oocytes by using the following equation: $I / I_{\mathrm{pH} \text { max }}=1 /\left\{1+\left(\mathrm{EC}_{50} /\left[\mathrm{H}^{+}\right]\right)^{n}\right\}=$ $1 /\left\{1+10^{n}(\mathrm{pH}-\mathrm{pH} 0.5)\right\}$, where $n$ is the Hill coefficient, and $\mathrm{EC}_{50}$ and $\mathrm{pH}_{0.5}$ are the proton concentration and $\mathrm{pH}$ yielding half of the saturating peak current amplitude $\left(I_{\mathrm{pH} \text { max }}\right)$. The $\mathrm{pH}_{\max }$ was determined by application of $\mathrm{pH} 5.0$ following $\mathrm{pH} 7.4$ ( $\mathrm{pH}$ concentration response of activation) or conditioning $\mathrm{pH} 7.9$ (steady-state desensitization). The $\mathrm{EC}_{50}$ for each peptide was calculated by fitting the data from individual oocytes by using the following equation: $I / I_{\max }=1 /\left\{1+\left(\mathrm{EC}_{50} /[\text { peptide }]\right)^{n}\right\}$, where $n$ is the Hill coefficient, and $\mathrm{EC}_{50}$ is the peptide concentration inducing half of the saturating peptide effect $\left(I_{\max }\right)$. Comparisons between groups were made with either a two-tailed Student's $t$ test with paired or unpaired data ( $p<0.05$ was considered significant) or ANOVA (one way or two way, as indicated) with Bonferroni's multiple-comparison test $[F$ values and degrees of freedom (between experimental groups and within datasets) are indicated in figure legends].

Mass culture of cortical and hippocampal neurons. Primary cortical and hippocampal neuron cultures were prepared using previously published methods (Askwith et al., 2004). Briefly, cerebral cortex and hippocampi were dissected from postnatal day $0-1$ pups, freed from extraneous tissue, and cut into pieces. Dissected tissue was transferred into Leibovitz's L-15 medium containing $0.25 \mathrm{mg} / \mathrm{ml}$ bovine serum albumin and 0.38 $\mathrm{mg} / \mathrm{ml}$ papain and incubated for $15 \mathrm{~min}$ at $37^{\circ} \mathrm{C}$ with $95 \% \mathrm{O}_{2}-5 \% \mathrm{CO}_{2}$ gently blown over the surface of the medium. After incubation, the dissected tissue was washed three times with mouse M5-5 medium (Earle's minimal essential medium with $5 \%$ fetal bovine serum, $5 \%$ horse serum, $0.4 \mathrm{~mm}$ L-glutamine, $16.7 \mathrm{~mm}$ glucose, $5000 \mathrm{U} / \mathrm{L}$ penicillin, $50 \mathrm{mg} / \mathrm{L}$ streptomycin, $2.5 \mathrm{mg} / \mathrm{L}$ insulin, $16 \mathrm{~nm}$ selenite, and $1.4 \mathrm{mg} / \mathrm{L}$ transferrin) and triturated. Dissociated cells were then centrifuged for $4.5 \mathrm{~min}$ at 730 $\mathrm{rpm}$ and M5-5 medium was aspirated. Cells were resuspended in supplemented neurobasal-A medium (1\% B27 supplement containing antioxidants, 1\% B27supplement minus antioxidants, $0.5 \mathrm{~mm}$ L-glutamine, 0.5 $\mathrm{mg} / \mathrm{ml}$ gentomycin, and $2.5 \mathrm{mg} / \mathrm{L}$ insulin, $16 \mathrm{~nm}$ selenite, and $1.4 \mathrm{mg} / \mathrm{L}$ transferrin). Cells were plated in 24-well plates containing $10 \mathrm{~mm}$ polyD-lysine-coated glass coverslips at a density of $5 \times 10^{4}$ cells per well. After $48-72 \mathrm{~h}, 10 \mu \mathrm{M}$ cytosine $\beta$-D-arabinofuranoside was added to inhibit glial proliferation. Neurons were maintained at $37^{\circ} \mathrm{C}$ with $5 \% \mathrm{CO}_{2}$ for 14-21 d before experiments were performed.

Whole-cell patch clamp on primary neurons. To record ASICdependent current, neurons were perfused with extracellular solution at varying $\mathrm{pH}$ values. The extracellular solution contained $140 \mathrm{~mm} \mathrm{NaCl}$, $5.4 \mathrm{~mm} \mathrm{KCl}, 10 \mathrm{~mm}$ HEPES buffer, $2 \mathrm{~mm} \mathrm{CaCl}, 1 \mathrm{~mm} \mathrm{MgCl}$, $5.55 \mathrm{~mm}$ glucose, $10 \mathrm{~mm}$ MES buffer, $10 \mu \mathrm{M}$ 6-cyano-7-nitroquinoxaline-2,3dione (CNQX), $50 \mu \mathrm{M} \mathrm{D}$-2-amino-5-phosphonovaleric acid (AP5), 30 $\mu \mathrm{M}$ bicuculline, and $500 \mathrm{~nm}$ tetrodotoxin. The $\mathrm{pH}$ was adjusted with $1 \mathrm{~N}$ $\mathrm{NaOH}$. Patch electrodes were fire polished with a microforge (Narishige). Micropipettes with 2-4 $\mathrm{M} \Omega$ were used for experiments. The intracellular pipette solution contained $121 \mathrm{~mm} \mathrm{KCl,} 10 \mathrm{~mm} \mathrm{NaCl}, 2 \mathrm{~mm}$ $\mathrm{MgCl}_{2}, 5 \mathrm{~mm}$ EGTA, $10 \mathrm{~mm}$ HEPES, $2 \mathrm{~mm} \mathrm{Mg-ATP}$, and $300 \mu \mathrm{M} \mathrm{Na}{ }_{3} \mathrm{GTP}$ (or $1 \mathrm{~mm} \mathrm{GDP} \beta$-s as indicated) (pH 7.25). The membrane potential was held constant at $-70 \mathrm{mV}$. Data were collected at $5 \mathrm{kHz}$ using an Axopatch 200B amplifier, Digidata 1322A, and Clampex 9 (Molecular Devices). Neurons were continuously superfused with the extracellular solution from gravity-fed perfusion pipes at a flow rate of $\sim 1 \mathrm{ml} / \mathrm{min}$. Perfusion pipes were placed $250-300 \mu \mathrm{m}$ away from cells, and flow was 
directed toward the recorded cells to ensure fast solution exchange. Maximal $\mathrm{H}^{+}$-gated current was evoked by the exogenous application of $\mathrm{pH}$ 6.5 from a holding $\mathrm{pH}$ of 7.9. Typically, three or four applications of $\mathrm{pH}$ 6.5 solution were required before $\mathrm{H}^{+}$-gated peak current amplitude stabilized. Once stabilized $\mathrm{H}^{+}$-gated current was established, experimental conditions were tested and peak current amplitude was normalized to the average peak current amplitude of flanking maximal $\mathrm{H}^{+}$-gated current. For experiments using GDP $\beta$-s, a minimum of 8 min was allowed for complete dialization of intracellular solution into the neuron before $\mathrm{H}^{+}$gated currents were recorded.

Acid-induced neuronal death assays. At 14-17 d in culture, cortical neurons were randomly divided into designated experimental groups (see Fig. 7). Neurobasal medium was removed before washing cells two times with ECF solution containing the following (in $\mathrm{mM}$ ): $140 \mathrm{NaCl}, 5.4$ $\mathrm{KCl}, 25 \mathrm{HEPES}$ buffer, 20 glucose, $1.0 \mathrm{CaCl}_{2}, 1.0 \mathrm{MgCl}_{2}, \mathrm{pH} 7.4(\mathrm{pH}$ adjusted with $1 \mathrm{~N} \mathrm{NaOH}$ ). Cells were then washed with pH 7.4 EFC inhibitor solution containing $10 \mu \mathrm{M}$ Dizocilpine (MK-801), $20 \mu \mathrm{M}$ CNQX, $5 \mu \mathrm{m}$ nimodipine, and $500 \mathrm{~nm}$ tetrodotoxin. Specific acidosis interventions were performed as described below (see Figure 7) in the presence and absence of big dynorphin using ECF with inhibitors. Within each culture, at least two different coverslips were used for a given intervention. Following acidosis interventions, cells were washed two times with $\mathrm{pH}$ 7.4 ECF without inhibitors, and fresh neurobasal culture medium was returned. Neurons were allowed to recover for $24 \mathrm{~h}$ at $37^{\circ} \mathrm{C}$ with $5 \% \mathrm{CO}_{2}$. After the recovery period, cells were incubated in ECF containing $5 \mu \mathrm{m}$ fluorescein diacetate (FDA) and $2 \mu \mathrm{M}$ propidium iodide (PI) for $30 \mathrm{~min}$ at room temperature (Gao et al., 2005). Cells were then washed four times with $\mathrm{Ca}^{2+}$-free PBS and fixed for $20 \mathrm{~min}$ in $4 \%$ paraformaldehyde. After fixing, cells were washed two additional times with PBS, and coverslips were then mounted on microscope slides. Pictures of five random fields of view demonstrating PI/FDA staining were taken for each coverslip (500-700 cells/coverslip) by an individual blinded to the experimental conditions. Images were obtained using a Zeiss Axioscope microscope at the $20 \times$ objective with 490 and $575 \mathrm{~nm}$ fluorescent filters (to observe FDA and PI fluorescence, respectively), an Axiocam digital camera, and Zeiss AxioVision 4.6 software. Images were pseudocolorized to distinguish labeling (green for FDA staining; red for PI staining). Live (FDA-stained cell bodies) and dead (PI-stained nuclei) cells were counted in each field by a blinded individual. Neuronal death was determined by averaging the percentage of dead cells on each coverslip; thus, one neuronal culture yielded one $n$ for a given acidosis intervention.

\section{Results}

\section{Dynorphin opioid peptides modulate ASIC1a} steady-state desensitization

Rapidly reducing the extracellular $\mathrm{pH}$ from $\mathrm{pH} 7.9$ to $\mathrm{pH} 5.0$ evoked large sodium currents in Xenopus laevis oocytes expressing ASICla (Fig. 1A). Steady-state desensitization of ASICla was induced by conditioning cells with $\mathrm{pH} 7.0$ for 2 min before application of an activating solution ( $\mathrm{pH}$ 5.0). This resulted in a loss of acid-evoked current (Fig. 1A). When dynorphin A was present, however, robust ASICla current was activated following pH 7.0 conditioning (Fig. 1A). Because dynorphin A did not enhance current in the absence of pH 7.0 conditioning (Fig. 1A), these results indicate that dynorphin A potentiates ASIC1a activity by inhibiting steady-state desensitization.

Dynorphin A is derived from the pre-prodynorphin precursor peptide, which produces several other biologically active neuropeptides (Fig. 1B) (Akil et al., 1984). These peptides and others structurally similar to dynorphins were tested to determine which dynorphin-related peptides alter ASICla activity. Big dynorphin (YGGFLRRIRPKLKWDNQKRYGGFLRRQFKVVT), a peptide that encompasses both dynorphin A and dynorphin $\mathrm{B}$ (Fischli et al., 1982), also limited steady-state desensitization of ASIC1a (Fig. 1C) and equal concentrations of big dynorphin had a more pronounced effect compared with dynorphin A (Fig. 1D). Neither leucine-enkephalin, $\alpha$ and $\beta$ neoendorphin, leumor-
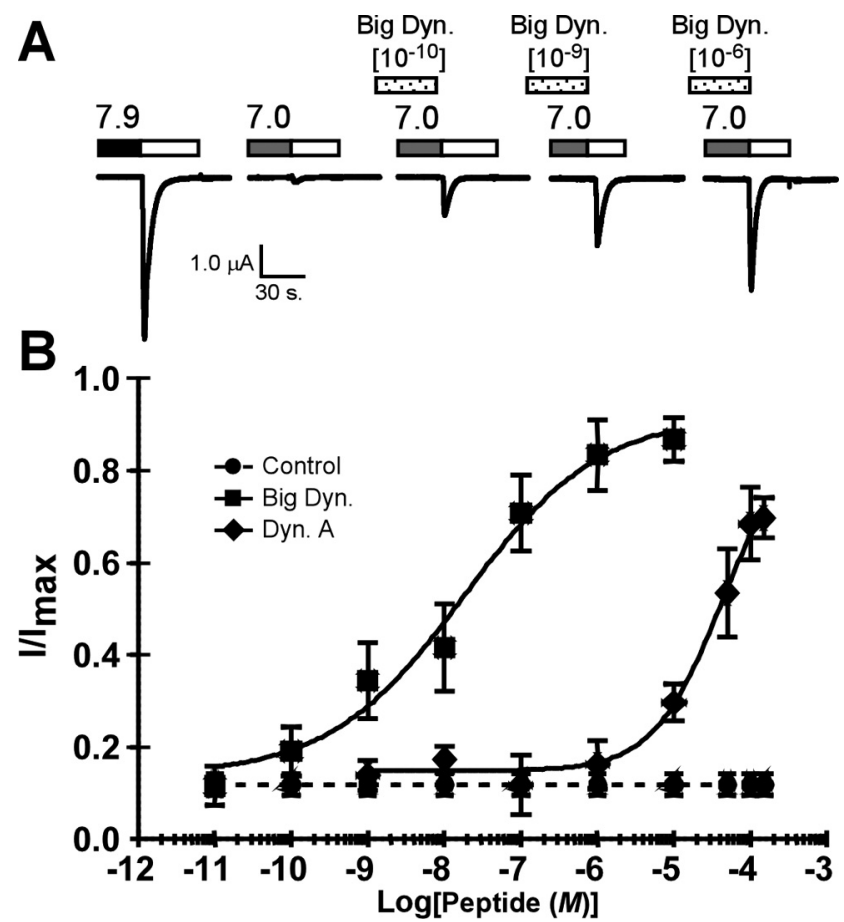

Figure 2. Dynorphin peptides modulate ASIC1a steady-state desensitization in a concentration-dependent manner. $\boldsymbol{A}$, Representative trace showing concentration dependence for big dynorphin modulation of ASIC1a expressed in oocytes. Peptides were applied the indicated concentrations and steady-state desensitization was induced by $\mathrm{pH} 7.0$ conditioning as before. ASIC1a current was evoked by application of pH 5.0. B, Quantification of peptide concentration effects on ASIC1a for dynorphin A and big dynorphin. Peak current amplitude was normalized to maximal current amplitude $\left(I / I_{\max }\right)$ in the absence of peptide. The data were fitted to a Hill equation with an $\mathrm{EC}_{50}$ of $32.8 \pm 11.5 \mu \mathrm{m}(n=8)$ for dynorphin $\mathrm{A}$ and an $\mathrm{EC}_{50}$ of $26.4 \pm 14.8 \mathrm{~nm}(n=6)$ for big dynorphin ( $p<0.001$ for peptide $\mathrm{EC}_{50}$; unpaired $t$ test). Error bars are the SEM. Dyn., Dynorphin.

phin, dynorphin B, nociceptin, orphanin FQ(160-187), nor nocistatin-35 affected ASIC1a steady-state desensitization (Fig. $1 C, D)$. These results suggest that specific dynorphin opioid peptides (dynorphin A and big dynorphin) limit ASIC1a steady-state desensitization.

Several other dynorphin-related peptide fragments were also tested in an effort to define the sequence necessary for dynorphin modulation of ASIC1a (Fig. 1D). We found that both nonopioid peptides dynorphin $\mathrm{A}(2-17)$ and big dynorphin(2-32) modulated ASICla steady-state desensitization. These two peptides lack the N-terminal tyrosine required for opioid receptor activation and are often used to distinguish between opioid- and nonopioid-mediated effects of dynorphins (Walker et al., 1982; Caudle and Mannes, 2000). None of the other dynorphin fragments tested modulated ASICla activity. Thus, the minimum sequence we identified as mediating ASICla modulation was dynorphin A(2-17) (Fig. 1E).

\section{Concentration dependence of dynorphin action on ASIC1a}

We next determined the concentrations of full-length dynorphins required to modulate steady-state desensitization of ASIC1a. Both dynorphin A and big dynorphin limited steadystate desensitization of ASIC1a in a concentration-dependent manner (Fig. 2). Dynorphin A had an $\mathrm{EC}_{50}$ of $32.8 \pm 11.5 \mu \mathrm{M}$ and did not affect ASICla steady-state desensitization at concentrations lower than $1 \mu \mathrm{M}$ (Fig. 2). These results are similar to those attained with RFamide-related peptide modulation of ASIC1a (Askwith et al., 2000; Sherwood and Askwith, 2008). However, 

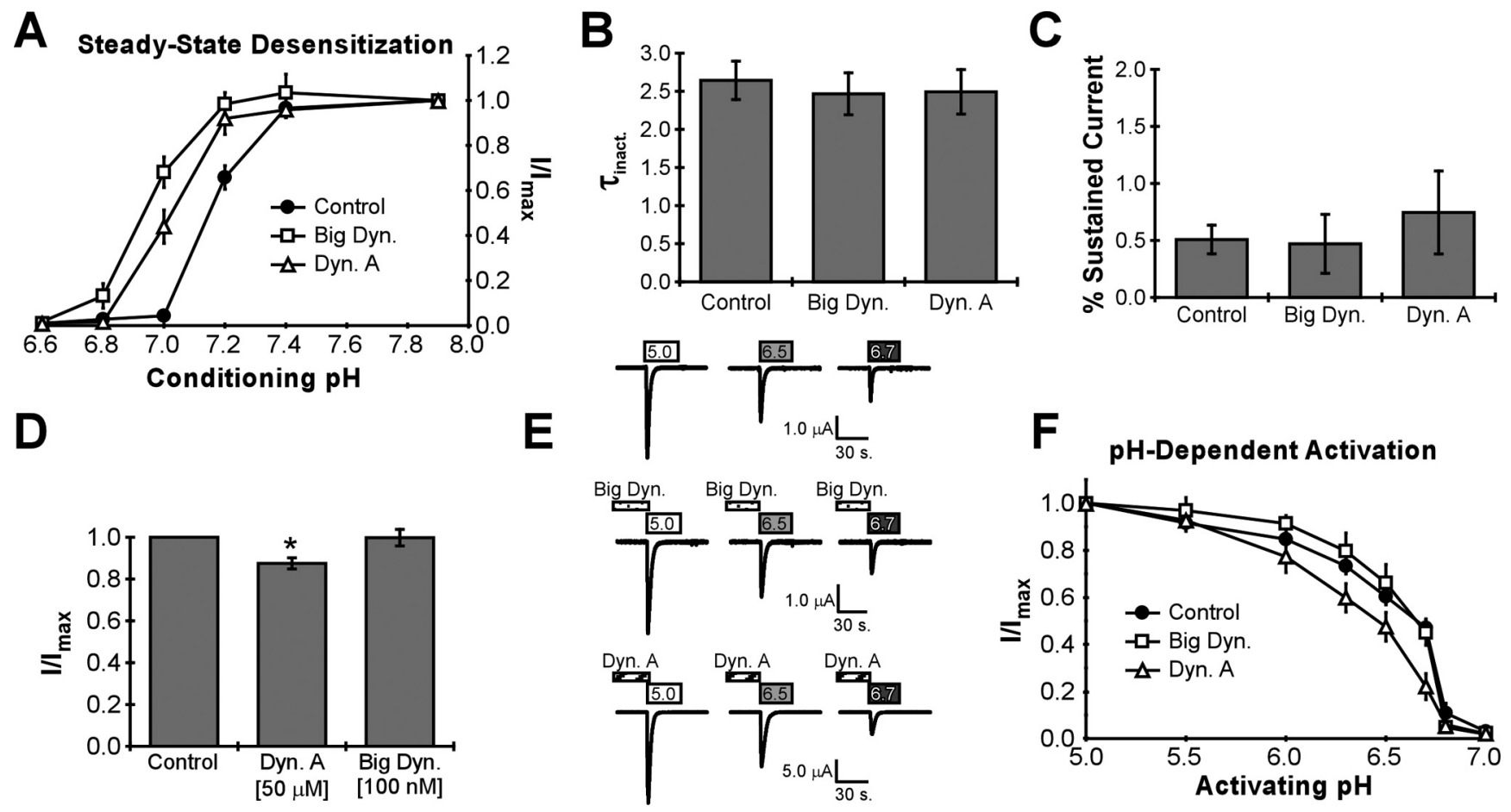

Figure 3. Dynorphin peptides alter the pH dependence for ASIC1a steady-state desensitization. A, Dynorphin A and big dynorphin cause acidic shift for ASIC1a steady-state desensitization. Steady-state desensitization was induced in ASIC1a-expressing Xenopus oocytes as before with the indicated conditioning pH solutions, and peptides were applied as before. Peak current amplitudes were normalized to maximal current amplitude (I/I $I_{\text {max }}$ ) for each condition (no peptide, $100 \mathrm{~nm}$ big dynorphin, or $50 \mu \mathrm{m} \mathrm{dynorphin} \mathrm{A).} \mathrm{All} \mathrm{ASIC} \mathrm{current} \mathrm{was} \mathrm{evoked} \mathrm{by} \mathrm{application} \mathrm{of} \mathrm{pH} 5.0$. The data were fitted to a Hill equation with $\mathrm{pH}_{0.5}$ values of $7.19 \pm 0.02$ for control $(n=6), 7.05 \pm 0.03$ for dynorphin $\mathrm{A}(n=5, p<0.05$ compared with control), and $6.99 \pm 0.02$ for big dynorphin $(n=$ $4, p<0.01$ compared with control). Statistics were performed using one-way ANOVA ( $F=12.95, \mathrm{df}: 2,12)$. $\boldsymbol{B}$, Peptide effects on current decay following activation. Peptides were applied at pH 7.9 (at concentrations above) for 2 min before application of pH 5.0. The $\tau_{\text {inact }}$ of acid-evoked currents in the absence or presence of peptide $(n=3-8)$ was calculated (in seconds) from data fitted to single exponential (see Materials and Methods) (one-way ANOVA, $F=0.1195$, df: 2, 13). C, Peptide effects on acid-dependent sustained current following activation. ASIC1a current was evoked in the presence or absence of peptide as above. Current during the plateau phase of decay was measured $30 \mathrm{~s}$ after application of $\mathrm{pH} 5.0$ and then normalized to peak current amplitude $(n=3-8$, one-way ANOVA, $F=0.3819, \mathrm{df}: 2,12)$. D, Peptide effects on maximal ASIC current. Peak current amplitude of pH 5.0-evoked current in the presence of peptide was normalized to peak current amplitude in the absence of peptide $(n=6-11, F=5.174, \mathrm{df}: 2,29)$. ${ }^{*} p<0.05$ (with one-way ANOVA). $\boldsymbol{E}, \boldsymbol{F}$, Representative traces $(\boldsymbol{E})$ and quantification $(\boldsymbol{F})$ of pH-evoked currents in $00 \mathrm{cytes}$ expressing ASIC1a. Basal extracellular pH was maintained at pH 7.4 and current was evoked by the indicated pH solutions. Big dynorphin $(0.1 \mu \mathrm{M})$ or dynorphin A (50 $\mu \mathrm{m})$ was applied at pH 7.4 for $2 \mathrm{~min}$ before application of acidic solutions. $1 / \mathrm{I}_{\mathrm{max}}$ is peak current amplitudes evoked by test $\mathrm{pH}$ values normalized to peak current amplitude evoked by pH 5.0 in the presence or absence of peptide. The data were fitted with a Hill equation with a $\mathrm{pH}_{0.5}$ for activation of $6.56 \pm 0.020$ for control $(n=4), 6.63 \pm 0.073$ for big dynorphin $(n=5)$, and $6.41 \pm 0.057$ ( $\left.n=4\right)$ for dynorphin A. Data were not statistically different in the presence of either dynorphin A or big dynorphin (one-way ANOVA, $F=4.126, \mathrm{df}: 2,9, p=0.0535$ ). Error bars are the SEM. Dyn., Dynorphin.

big dynorphin prevented $\mathrm{pH}$ 7.0-induced desensitization at concentrations as low as $0.1 \mathrm{~nm}$ with an $\mathrm{EC}_{50}$ of $26.4 \pm 14.8 \mathrm{~nm}$ (Fig. 2 ). This is within the range of the effective concentrations for other previously identified nonopioid targets of dynorphins, including the NMDA $\left(\mathrm{EC}_{50}\right.$ of $\left.3.5 \mathrm{nM}-1.6 \mu \mathrm{M}\right)$ and bradykinin $\left(\mathrm{EC}_{50}\right.$ of $\sim 1 \mu \mathrm{M}$ ) receptors (Chen et al., 1995; Caudle and Dubner, 1998; Lai et al., 1998, 2008). In addition, the $\mathrm{EC}_{50}$ of big dynorphin was much lower than any endogenous peptide previously reported to modulate ASIC1a activity (Askwith et al., 2000; Sherwood and Askwith, 2008).

\section{Dynorphin peptides alter the proton dependence of ASIC1a steady-state desensitization}

We tested whether dynorphin A and big dynorphin modulate ASICla current by altering the apparent proton affinity for steady-state desensitization, a mechanism used by RFamiderelated neuropeptides (Sherwood and Askwith, 2008). In the absence of peptide, steady-state desensitization was induced by conditioning with extracellular solutions at $\mathrm{pH}<7.4$, and $\mathrm{pH}$ 5.0-evoked current was almost completely inhibited by conditioning in $\mathrm{pH} 7.0$ (Fig. $3 A$ ). In the presence of either dynorphin $\mathrm{A}$ or big dynorphin, solutions below $\mathrm{pH} 7.2$ were required for steady-state desensitization, and complete desensitization of
ASIC1a was not observed above $\mathrm{pH} 6.8$ (Fig. 3A). Thus, the $\mathrm{pH}$ dependence of steady-state desensitization was shifted in the presence of dynorphin A and big dynorphin such that moreacidic $\mathrm{pH}$ values were required to desensitize the channel.

We also examined the effect of dynorphins on other characteristics of ASIC1a. Neither big dynorphin nor dynorphin A altered current decay following activation as measured by the $\tau_{\text {inact }}$ (Fig. 3B). Neither peptide induced an acid-dependent sustained current in the plateau phase of current decay as RFamide peptides commonly do (Fig. 3C). Dynorphin A induced a small, but significant ( $p<0.05$ versus control), decrease in maximal $\mathrm{pH} 5.0$ evoked current amplitude (Fig. 3D). Yet, big dynorphin had no effect on maximal current amplitude $(p>0.05)$. A small decrease in the apparent proton sensitivity of ASIC1a activation was observed in the presence of dynorphin A (Fig. 3E). However, the $\mathrm{pH}_{0.5}$ for activation was not statistically different in the presence of either dynorphin A or big dynorphin (control $\mathrm{pH}_{0.5}=6.56 \pm$ 0.020 , big dynorphin $\mathrm{pH}_{0.5}=6.63 \pm 0.073, p>0.05$ versus control, dynorphin $\mathrm{A} \mathrm{pH}_{0.5}=6.41 \pm 0.057, p>0.05$ versus control) (Fig. $3 F$ ). These results suggest that dynorphin peptides potentiate ASICla current by predominantly limiting steadystate desensitization, although dynorphin A also subtly affects other characteristics of ASIC1a. 
A
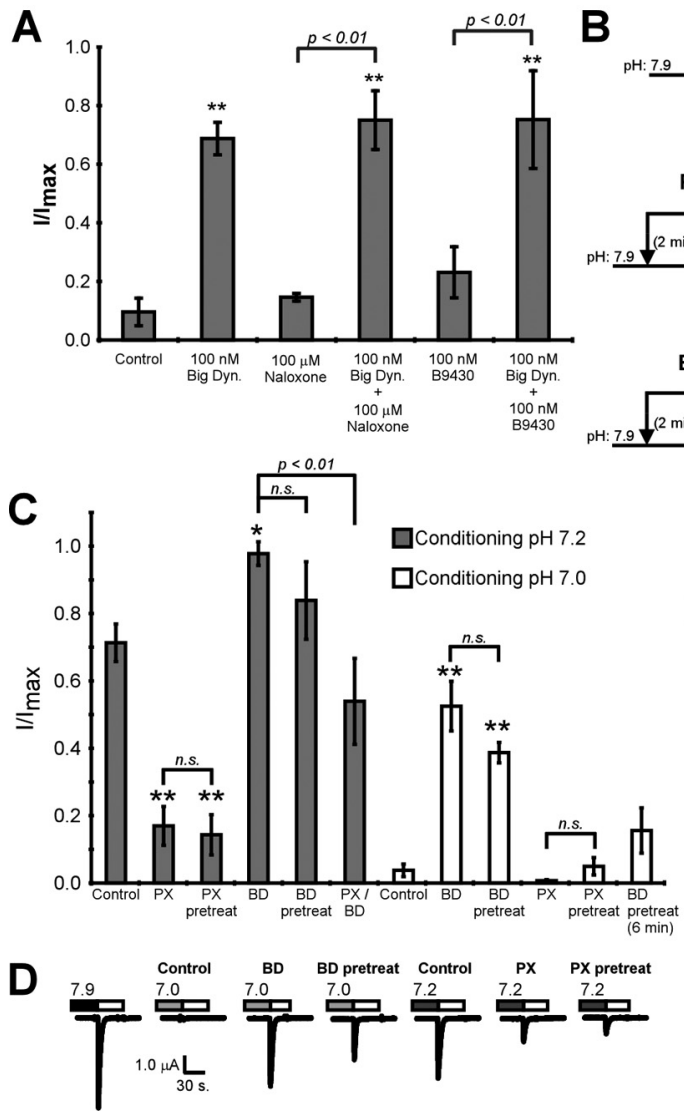
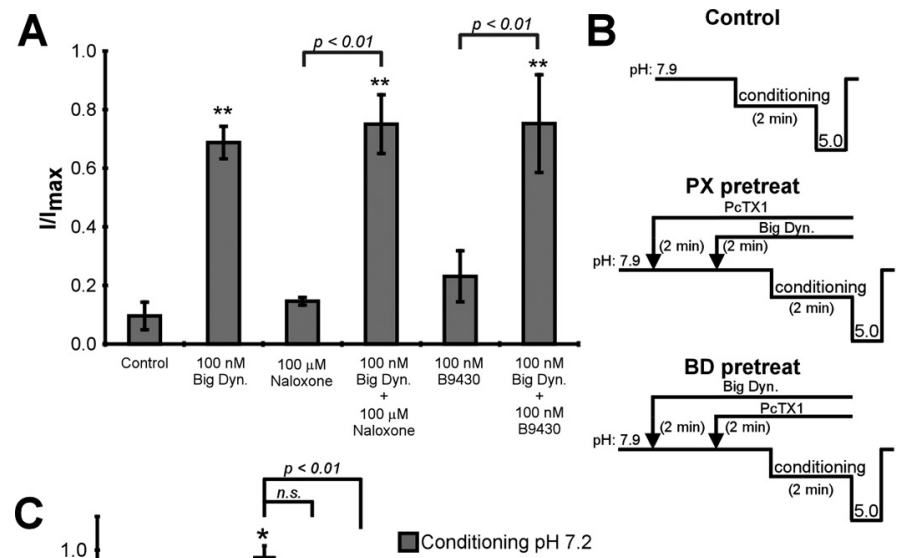

$\mathbf{E}$
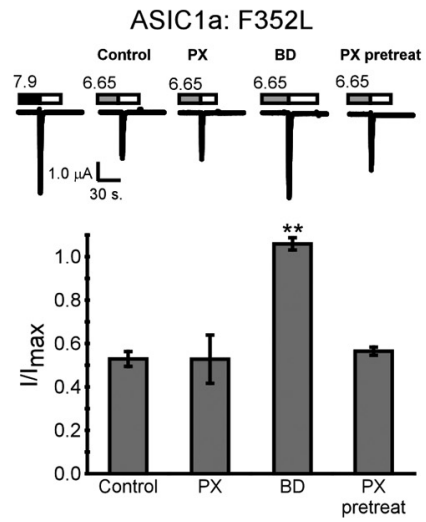

Figure 4. Big dynorphin modulates ASIC1a in an opioid/bradykinin receptor-independent mechanism and competitively prevents PCTx1 modulation. $\boldsymbol{A}$, 0pioid and bradykinin receptor antagonists fail to prevent big dynorphin modulation of ASIC1a. Steady-state desensitization of ASIC1 1 a was induced by conditioning with pH 7.0 as before. Big dynorphin, naloxone, or B9430 was applied for 2 min before (at pH 7.9) and during conditioning with pH 7.0 before activation with pH 5.0. Peak current amplitudes were normalized to maximal current amplitude in the absence of peptide and antagonists ( $n=3-9, F=18.66$, df: 5,32 ). $\boldsymbol{B}$, Schematic illustrating experimental protocol of big dynorphin competition with PCTx1 for ASIC1a modulation. Relative time is represented on horizontal axis and $\mathrm{pH}$ is shown on vertical axis. Arrows show application of big dynorphin (1 $\mu \mathrm{M})$ or PCTx1 (0.2 $\mu \mathrm{M})$. Conditioning pH was 7.0 or 7.2 as indicated in $\boldsymbol{C}$ and $\boldsymbol{D}$. Conditioning pH 7.0 highlights big-dynorphin-mediated inhibition of steady-state desensitization, whereas pH 7.2 better reveals PcTx1-mediated enhancement of steady-state desensitization. $\boldsymbol{C}, \boldsymbol{D}$, Quantification $(\boldsymbol{C})$ and representative traces $(\boldsymbol{D})$ showing big dynorphin and PcTx1 compete for modulation of ASIC1a steadystate desensitization. In the "BD pretreat $(6 \mathrm{~min})$ " condition, big dynorphin was preapplied for 2 min and then big dynorphin and PCTx1 were coapplied for 6 min before conditioning (rather than $2 \mathrm{~min}$ ). Peak current amplitudes in each condition were normalized to maximal current amplitude in the absence of peptide $\left(I / I_{\text {max }}\right)\left(n=4-11, F_{\mathrm{pH} 7.2}=25.04, \mathrm{df}_{\mathrm{pH} 7.2}: 5,31, F_{\mathrm{pH} 7.0}=21.99\right.$, $\left.\mathrm{df}_{\mathrm{pH7} .0}: 5,30\right) . \boldsymbol{E}$, Representative trace and quantification showing that PcTx1 prevents the effects of big dynorphin on ASIC1a:F353L mutant. Peptide treatments were performed as before except that the conditioning pH was 6.65 ( $n=3, F=49.66$, df: 3,8). Data were analyzed using a one-way ANOVA. ${ }^{*} p<0.05$ and ${ }^{* *} p<0.01$ compared with control. Error bars are the SEM. Dyn., Dynorphin; BD, big dynorphin; PX, PCTx1.

\section{Big dynorphin modulates ASIC1a in an opioid/bradykinin receptor-independent mechanism}

Dynorphins are neuropeptides with a high affinity for the $\kappa$-opioid receptors, but they also activate $\mu$ - and $\delta$-opioid receptors as well as bradykinin receptors (Wollemann and Benyhe, 2004; Hauser et al., 2005; Lai et al., 2006). To determine whether big dynorphin potentiates ASIC1a current via an opioid or bradykinin receptor-dependent mechanism, we tested the ability of big dynorphin to enhance ASIC1a current in the presence of antagonists for these receptors. Conditioning cells with $\mathrm{pH} 7.0$ reduced $\mathrm{pH}$ 5.0-evoked current to $10.4 \pm 3.6 \%$ of maximal current and application of either the opioid receptor antagonist naloxone or the bradykinin receptor antagonist B9430 had no effect on $\mathrm{pH}$ 7.0-induced desensitization (Fig. 4A). Treatment with 100 $\mathrm{nM}$ big dynorphin potentiated ASIC current to $69.0 \pm 7.6 \%$ of maximal current and this effect was not prevented by treatment
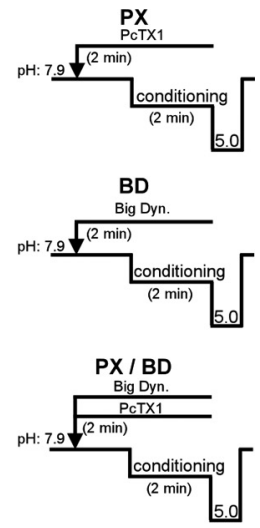

with either naloxone or B9430, suggesting that big dynorphin potentiates ASICla current independent of opioid and bradykinin signaling (Fig. 4A).

\section{Dynorphin competes with PcTx1 for ASIC modulation}

Because opioid and bradykinin antagonists failed to prevent the effects of big dynorphin, we considered that the peptide may act directly on ASIC1a to limit steady-state desensitization. Big dynorphin and PcTx1 both alter steady-state desensitization of ASICla, and PcTxl is known to interact directly with the extracellular domain of ASIC1a (Escoubas et al., 2000; Chen et al., 2005; Salinas et al., 2006). We hypothesized that if big dynorphin acts directly on ASICla at the PcTx1 binding site, then the presence of PcTx1 may prevent big dynorphin modulation of steady-state desensitization. Therefore, we tested the effects of these peptides on ASIC1a activity when they were added alone and together (Fig. 4B). When PcTx1 was present alone, steady-state desensitization induced by $\mathrm{pH} 7.2$ was enhanced and acid-evoked current was reduced (Fig. 4C,D). When big dynorphin was present alone, steady-state desensitization of $\mathrm{pH} 7.2$ was inhibited and more ASIC1a current was evoked. When both peptides were applied simultaneously, an intermediate effect was observed (Fig. $4 C, D)$. However, if PcTx1 was applied for 2 min before application of the mixed PcTx1 and big dynorphin solution (Fig. 4, "pretreat"), then a predominantly PcTx1like effect was observed and ASIC1a current remained desensitized (Fig. $4 B-D$ ). Pretreatment with big dynorphin for 2 min before incubation with the mixed solution of PcTx1 and big dynorphin resulted in a predominantly big-dynorphinlike effect. Similar results were observed after conditioning with $\mathrm{pH} 7.0$, which better reveals big-dynorphin-mediated inhibition of steady-state desensitization (Fig. 4B-D). Since pretreatment with one peptide prevented the effects of the other, we examined big dynorphin modulation of NMDA current (a known target of big dynorphin but not PcTx1). Big dynorphin modulation of NMDA-evoked current in hippocampal neurons was not affected by the presence of PcTx1 (supplemental data, available at www.jneurosci.org as supplemental material; Fig. 1), indicating that big dynorphin and PcTx1 do not associate together directly to prevent NMDA receptor modulation.

Because each peptide could prevent the ASICla modulatory effects of the other, we reasoned that big dynorphin and PcTx1 might compete for ASIC1a binding. In support of this, the effect of big dynorphin pretreatment was attenuated following an extended coapplication period of 6 min [Fig. $4 C$, "BD pretreat $(6$ min)"]. Thus, when enough time was allowed for peptide competition to come to equilibrium an intermediate effect on ASIC1a 
current was observed. These results suggest either that PcTx1 and big dynorphin compete for binding to ASICla or that binding of either peptide stabilizes ASICla in a conformational state that prevents binding of the other peptide. Big dynorphin action is dependent on the state of the channel, and desensitized channels are unresponsive to big dynorphin (supplemental data, available at www.jneurosci.org as supplemental material; Fig. 2). However, we also tested whether PcTxl could prevent big dynorphin modulation of a mutant ASICla channel (ASIC1a:F352L) that is unresponsive to PcTx1 (Fig. 4E) (Sherwood et al., 2009). Treatment with big dynorphin alone prevented steady-state desensitization of ASIC1a:F352L, but PcTx1 alone had no effect. However, pretreatment with PcTx1 prevented big dynorphin modulation (Fig. 4E). Because PcTx1 did not produce a functional effect on its own, these results suggest that PcTx1 binding itself (rather than PcTx1-induced gating changes) prevented big dynorphin action. Together, these results suggest that big dynorphin interacts directly with ASICla and binding of either PcTx1 or big dynorphin decreases the ability of the other peptide to affect channel activity.

\section{ASIC1 subunits are affected by big dynorphin}

Functional ASICs are composed of three ASIC subunits and can be homomeric or heteromeric (Wemmie et al., 2006). Our results show that big dynorphin modulates ASICla homomeric channels. However, acid-activated current in the CNS is due to ASIC1a homomeric channels and ASIC1a/ASIC2a heteromeric channels (Askwith et al., 2004). ASIC1b and ASIC3 form functional homomeric and heteromeric channels and are coexpressed in some neurons of the peripheral nervous system (Bässler et al., 2001; Benson et al., 2002; Ugawa et al., 2005). To determine whether big dynorphin modulation is specific to ASIC1a homomers, we tested peptide modulation on cells expressing other ASIC subunits (Fig. 5). Big dynorphin prevented steady-state desensitization of both ASICla and ASIClb homomeric channels (Fig. 5). Big dynorphin had a more modest affect on cells expressing both ASIC1a and ASIC2a ( $p=0.021$ compared with control) suggesting ASICla/2a heteromeric channels are not as sensitive to big dynorphin. Further, big dynorphin failed to modulate steady-state desensitization when ASIC1b was coexpressed with ASIC3. These results indicate that big dynorphin modulation of ASICs is dependent on the subunit composition of the channel. Specifically, big dynorphin modulates ASIC1 homomeric channels but the presence of ASIC2a or ASIC3 in heteromeric channels attenuates peptide effects.

\section{Big dynorphin prevents steady-state desensitization of proton-gated currents in primary cortical neurons}

The ability of big dynorphin to modulate proton-gated current in cultured cortical neurons was assessed using the whole-cell patch clamp. Application of $\mathrm{pH} 6.5$ preferentially activates ASICla homomultimeric channels (Askwith et al., 2004) and evoked a large

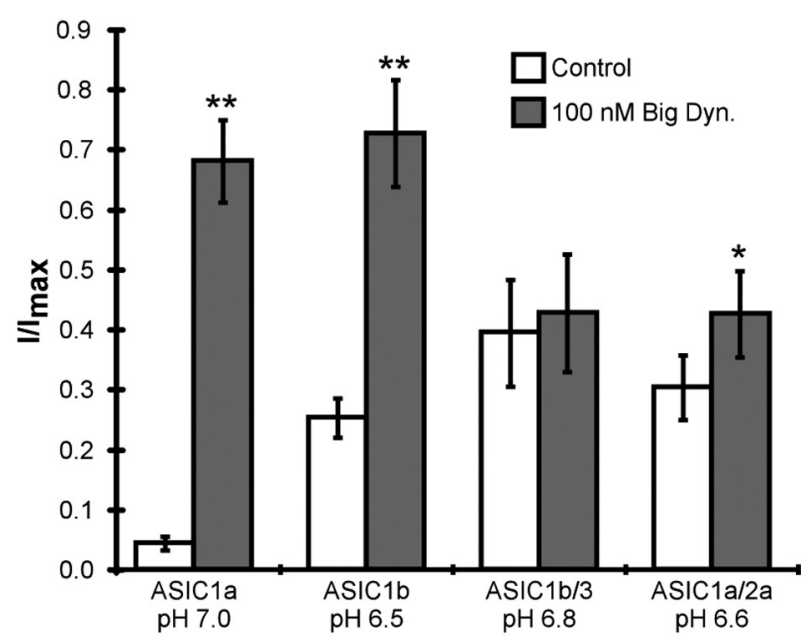
tioning neurons with extracellular $\mathrm{pH} 7.2$ reduced $\mathrm{pH}$ 6.5-evoked current to $21.1 \pm 1.6 \%$ of maximal current. In the presence of big dynorphin, the $\mathrm{pH}$ 6.5-evoked current following conditioning was $50.2 \pm 2.2 \%$ of maximal current (Fig. $6 \mathrm{~A}$ ). Thus, big dynorphin inhibited steady-state desensitization of proton-gated currents in cortical neurons. Similar to our previous results with oocytes expressing ASIC1a, big dynorphin shifted the $\mathrm{pH}$ dependence of steady-state desensitization to more-acidic values (Fig. $6 \mathrm{~B})$. We also tested whether naloxone and B9430 could perturb big-dynorphin-mediated effects on proton-gated current in neurons (Fig. $6 C$ ). Big dynorphin similarly potentiated proton-gated current in the presence of both naloxone and B9430, neither of which had any affect on proton-gated currents alone. We also replaced GTP in the patching electrode with $1 \mathrm{~mm}$ GDP $\beta$-s, an inhibitor of GTPase activity and therefore an inhibitor of G-protein-dependent signaling (Fig. 6D). We found that proton-gated current was potentiated by big dynorphin equivalently in the presence of GDP $\beta$-s or normal GTP (Fig. 6D). Together, these results indicate that big dynorphin acts independent of opioid receptors, bradykinin receptors, or G-proteins to potentiate proton-gated currents in neurons by limiting steady-state desensitization.

\section{Big dynorphin enhances ASIC1-mediated neuronal death in} cortical neurons

Activation of ASICla during prolonged acidosis accompanying an ischemic cerebral injury contributes to neuronal death in vivo (Xiong et al., 2004; Pignataro et al., 2007). Prolonged incubation with acidic extracellular solution also induces ASICla-dependent death of cultured cortical neurons (Xiong et al., 2004; Gao et al., 2005). Because steady-state desensitization prevents ASICla activation, we hypothesized that steady-state desensitization of 
A
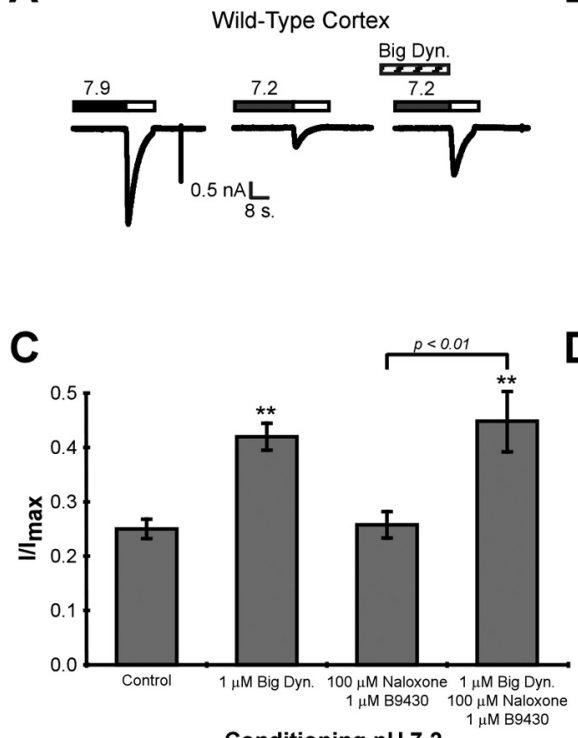

Conditioning pH 7.2

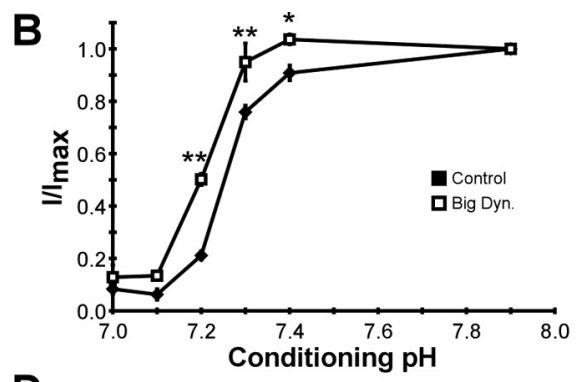

D

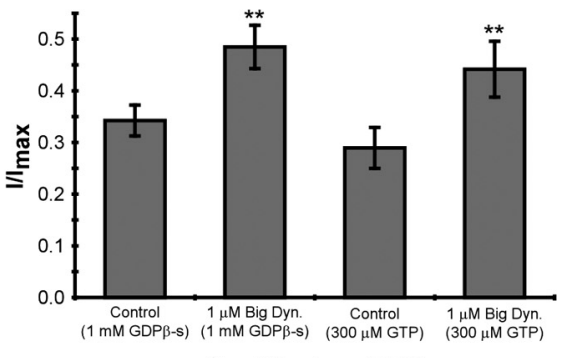

Conditioning pH 7.2

Figure 6. Big dynorphin modulates steady-state desensitization of proton-gated currents in primary cortical neurons. $A$, Representative trace of the effects of big dynorphin on proton-gated current in cortical neurons. Whole-cell patch-clamp technique was used to record pH 6.5-evoked currents in day 14-21 wild-type cultured neurons. Experiments were done in the presence of NMDA receptor, AMPA receptor, GABA receptor, and voltage-gated sodium channel inhibitors (see Materials and Methods). "Maximal current" was considered current evoked by perfusion of pH 6.5 (white bars) from a holding pH of 7.9. Steady-state desensitization was induced by perfusing cells with pH 7.2 for $1.5 \mathrm{~min}$. Big dynorphin $(1 \mu \mathrm{M})$ was applied for $1.5 \mathrm{~min}$ before (at pH 7.9) and 1.5 min during conditioning with pH 7.2. B, Big dynorphin causes an acidic shift for steady-state desensitization of proton-gated current. Steady-state desensitization was induced in neurons as before with the indicated conditioning pH solutions. Peptide was applied as before. Peak current amplitude was normalized to maximal current amplitude $\left(I / I_{\text {max }}\right)$ for each condition (no peptide, $1 \mathrm{~mm}$ big dynorphin). Proton-gated current was always evoked by perfusion of $\mathrm{pH}$ 6.5. $(n=5-10)$. A two-way ANOVA was done to assess significance $\left(F_{\text {peptide }}=52.48, \mathrm{df}_{\text {peptide }}: 1, F_{\mathrm{pH}}=435.4, \mathrm{df}_{\mathrm{pH}}: 5, F_{\text {interaction }}=6.991, \mathrm{df}_{\text {interaction }}: 5\right) .{ }^{*} p<0.05$, ${ }^{* *} p<0.01$ compared with control. C, Opioid and bradykinin receptor antagonists do not prevent the effects of big dynorphin. Steady-state desensitization of ASIC1a was induced by conditioning with pH 7.2 as before. Big dynorphin, naloxone, and B9430 were applied at the indicated concentrations for $1.5 \mathrm{~min}$ before (at pH 7.9) and during conditioning with pH 7.2. Peak current amplitudes were normalized to maximal current amplitude in the absence of peptide and antagonists ( $n=4-10, F=12.87$, df: 3,30). Data were analyzed using one-way ANOVA. ${ }^{* *} p<0.01$. D, Big dynorphin acts independently of G-protein-dependent signaling. Proton-gated current was recorded with normal GTP (300 $\mu \mathrm{m})$ or GDP $\beta$-s (1 mM) in the patching electrode. Steady-state desensitization was induced by conditioning with pH 7.2 as before. Big dynorphin was applied as before. Peak current amplitudes were normalized to maximal current amplitude in the absence of peptide $(n=4-6) .{ }^{* *} p<0.02$ using a Student's $t$ test. Error bars are the SEM. Dyn., Dynorphin.

ASIC1a would prevent acidosis-induced neuronal death. To focus on acidosis-induced neuronal death, these experiments were done in the presence of blockers of excitotoxicity, including NMDA channel inhibitors (see Materials and Methods). We compared cortical neurons that underwent acidosis for $1 \mathrm{~h}$ to neurons in which steady-state desensitization of proton-gated currents was induced by conditioning with $\mathrm{pH} 7.0$ for 2 min before acidosis, and neurons that did not undergo acidosis (Fig. $7 A$ ). Following acidosis and recovery, neurons were labeled with FDA and PI. Quantification of FDA-labeled cells (live) versus PIlabeled cells (dead) revealed a significant increase in dead neurons that were treated with acid compared with control neurons (Fig. $7 B, C$ ). However, neurons that were conditioned with $\mathrm{pH}$ 7.0 before acidosis showed no increase in death compared with neurons that did not undergo acidosis. These data indicate that induction of ASIC1a steady-state desensitization is neuroprotective during prolonged acidosis.

Because big dynorphin prevented steady-state desensitization of ASICla, we tested its effects on acid-induced death. We found that treatment with big dynorphin completely prevented the neuronal protection induced by steady-state desensitization but did not induce death in the absence of acidosis (Fig. 7C). Impor- tantly, ASIC1 knock-out neurons did not exhibit acidosis-induced death in the presence or absence of big dynorphin (Fig. 7D). Thus, big dynorphin enhances acidosis-induced neuronal death under conditions that normally induce steadystate desensitization of ASICla.

\section{Discussion}

We show, for the first time, that ASICla is potentiated by the opioid peptides dynorphin A and big dynorphin. Thus, ASIC1a is a novel target for dynorphin peptide action. Dynorphin-related opioid agonists are known to interact with several subtypes of GPCRs (opioid, nociceptin, and bradykinin) as well as the NMDA receptor ion channel (Höllt, 1986; Caudle and Mannes, 2000; Wollemann and Benyhe, 2004; Lai et al., 2006). In the latter case, dynorphin A binds directly to the extracellular domain of the NMDA receptor to alter channel activity (Massardier and Hunt, 1989; Chen et al., 1995; Woods et al., 2006). Our data support a similar mechanism for dynorphin modulation of ASIC1a activity. Specifically, we find that (1) preventing opioid receptor or bradykinin receptor activation does not inhibit dynorphin action; (2) inhibiting G-protein action does not alter dynorphin-induced modulation of ASIC1a; (3) other dynorphin-related peptide agonists of GPCRs do not modulate ASICla; (4) the nonopioid dynorphin peptides (2-17 and 2-32) modulate ASIC1a; (5) dynorphin A and big dynorphin have distinct effects on ASICla and vastly different concentration dependences for ASIC modulation, which is not reflective of their relative affinities for other known receptors; and (6) the venom peptide PcTx1 and big dynorphin compete for modulation of ASIC1a. PcTx1 specifically binds the extracellular domain of ASIC1 to enhance the proton sensitivity of steady-state desensitization (an action in opposition to big dynorphin) (Escoubas et al., 2000; Chen et al., 2006a; Salinas et al., 2006). Although direct assessment of big dynorphin interaction with the channel will require detailed binding studies, our results suggest that big dynorphin interacts directly with ASIC1a, at a location possibly overlapping the PcTx1 binding site.

ASICs mediate the neuronal response to extracellular acidosis. However, ASICs undergo steady-state desensitization during gradual or incremental reductions in $\mathrm{pH}$ (Babini et al., 2002). Once desensitized, ASICs fail to activate, even when the acidic threshold for activation is reached. Dynorphins decrease the apparent proton sensitivity of ASICla steady-state desensitization; thus, more-acidic $\mathrm{pH}$ values are required to induce steady-state desensitization of ASIC1a in the presence of dynorphin A or big dynorphin. RFamide-related peptides are also thought to potentiate ASIC1a activity by interacting directly with the extracellular domain of ASICla and limiting steady-state desensitization (Askwith et al., 2000; Chen et al., 2006b; Sherwood and Askwith, 2008). Whether dynorphins and RFamides modulate ASICla activity 
through the same molecular mechanism is not known. However, there are significant differences between RFamide and big dynorphin modulation. First, some RFamides slow the rate of inactivation, whereas big dynorphin does not alter inactivation of ASIC1a (Askwith et al., 2000; Deval et al., 2003). These results suggest that steady-state desensitization and inactivation may be distinct processes, although certain modulators can affect both properties. Second, FMRFamide does not compete with PcTxl (Salinas et al., 2006) or big dynorphin (T. Sherwood and C. Askwith, unpublished data). Finally, ASIC3/ASIC1b and ASIC1a/2a heteromeric channels respond very robustly to RFamides (Askwith et al., 2004; Chen et al., 2006b), whereas these heteromeric channels show little to no modulation by big dynorphin.

Big dynorphin is a common dynorphin peptide produced and released from many areas that also produce dynorphins A and B (Cone et al., 1983). A specific physiological role for big dynorphin in vivo has not yet been determined, but administration of big dynorphin in animals produces both novel and overlapping effects compared with dynorphin $\mathrm{A}$ and dynorphin B (Tan-No et al., 2002; Kuzmin et al., 2006). Our data indicate that big dynorphin has a preferential ability to modulate ASIC1a activity compared with dynorphins $\mathrm{A}$ and $\mathrm{B}$. The $\mathrm{EC}_{50}$ for big dynorphin modulation of ASIC1a is $26 \mathrm{~nm}$ and modulation is evident with $1 \mathrm{~nm}$ peptide. The concentration of dynorphin A has been estimated in the mid to high nanomolar range in the CNS and the concentration of big dynorphin has been reported to be $\sim 10$-fold less $(\sim 1-7 \mathrm{nM})$ in whole-tissue homogenates (Goldstein and Ghazarossian, 1980; Andrews et al., 1988; Merg et al., 2006). Dynorphin levels can also increase after injury and are more concentrated within the synaptic cleft after synaptic release (estimated in the low micromolar range) (Chen et al., 1995; Hauser et al., 2005; Schwarzer, 2009). Thus, big dynorphin modulation of ASIC1a may occur in vivo under both normal and pathophysiological conditions.

There are several parallels between the role of dynorphin and ASIC1a in the nervous system. Dynorphins are very highly expressed in the amygdala and promote learning and memory induced by adversive stimulation through both opioid and nonopioid mechanisms (Kuzmin et al., 2006; Schwarzer, 2009). ASICla is also highly expressed throughout the amygdala and affects learning and memory in response to fear (Wemmie et al., 2003; Coryell et al., 2008). Both ASICla and dynorphin also contribute to pain and nociception (Wollemann and Benyhe, 2004; Altier and Zamponi, 2006; Mazzuca et al., 2007). Interestingly, the analgesic effect of ASICla inhibition is thought to be due to stimulation of enkephalin release and activation of $\mu$ - and $\delta$-opioid receptors (Mazzuca et al., 2007). Thus, there is significant cross talk between the opioid and ASIC signaling pathways with opioids modulating ASIC activity and ASIC activity modulating opioid signaling. Yet, it should be noted that dynorphin modulates the response of ASIC1a to mild long-lasting acidosis, and it is not known how this would contribute to ASIClamediated signaling normally. Our data support a more direct role for dynorphins in ASIC1a-mediated neuronal death.

Both big dynorphin and dynorphin A have been implicated in neuronal damage and death (Faden, 1996; Tan-No et al., 2001; Hauser et al., 2005). Dynorphin A strongly contributes to damage following traumatic injuries to the brain and spinal cord (Hauser et al., 2005). Dynorphin A protein levels increase at injury sites in proportion to the severity of the injuries (McIntosh et al., 1987). Neutralizing antibodies to dynorphin A have shown potent neuroprotective effects when administered in mouse models of spinal cord injury (Winkler et al., 2002; Hauser et al., 2005). Although high doses of opiate receptor antagonists partially alleviated the severity of these injuries, it is thought that this may be due to their ability to re-establish blood flow to the traumatized areas (McIntosh et al., 1987). Administration of dynorphin A alone can also cause permanent damage to the spinal cord that can be prevented by administration of NMDA receptor blockers (Caudle and Mannes, 2000). However, secondary ischemia and acidosis often accompany neuronal injuries during the time of dynorphin elevation and neurotoxicity. In particular, traumatic brain injury is accompanied by profound cerebral acidosis, the severity of which correlates with the degree of permanent brain injury (Siesjö et al., 1996; Clausen et al., 2005). Our data suggest that some of the pathophysiological effects of dynorphins are mediated through enhancement of ASICla activity and acidosisinduced neuronal death. 
Extracellular $\mathrm{pH}$ reductions under pathological conditions are usually gradual [taking minutes to develop (von Hanwehr et al., 1986; Harris et al., 1987)]. Thus, steady-state desensitization may be an intrinsic neuroprotective mechanism to prevent ASIC1a activation during pathological acidosis. Our finding that conditions which induce steady-state desensitization prevent acidosis-induced neuronal death supports this hypothesis. We find that big dynorphin allows the channel to be responsive to acid even during incremental $\mathrm{pH}$ decreases and dramatically enhances acidosis-induced neuronal death following incremental acidosis. These effects would be particularly important during pathological decreases in extracellular $\mathrm{pH}$ accompanying ischemia, inflammation, injury, or seizure. In addition, conditions which increase dynorphin levels may increase susceptibility to acidosis-induced neuronal death and result in poor prognosis following cerebral injuries (Hauser et al., 2005). ASIC1a has also been implicated in neuronal death accompanying multiple sclerosis, Huntington's disease, and Parkinson's disease (Friese et al., 2007; Arias et al., 2008; Wong et al., 2008). Thus, our finding that dynorphin A and big dynorphin enhance ASIC1a activity and acidosis-induced neuronal death is relevant to multiple situations that cause permanent brain injury.

Dynorphin peptides have also been reported to have a neuroprotective role during cerebral injury and ischemia (Faden, 1996; Hauser et al., 2005). The conflicting roles of dynorphins are likely due to their ability to activate multiple GPCRs [generally neuroprotective (Zhang et al., 2003)] and directly modulate ion channels causative to neuronal death [NMDA receptors (Caudle and Mannes, 2000) and ASICs]. The identification of ASICla as a novel target for dynorphins helps in the understanding of the neurotoxic and neuroprotective roles of dynorphins. We hypothesize that the net function of dynorphins in neuronal injury depends on (1) the specific peptides expressed (dynorphin A and dynorphin B versus big dynorphin), (2) the complement of dynorphin targets expressed in the affected neurons (both GPCRs and ion channels), and (3) the extent of extracellular acidosis.

\section{References}

Akil H, Watson SJ, Young E, Lewis ME, Khachaturian H, Walker JM (1984) Endogenous opioids: biology and function. Annu Rev Neurosci 7:223-255.

Altier C, Zamponi GW (2006) Opioid, cheating on its receptors, exacerbates pain. Nat Neurosci 9:1465-1467.

Andrews BT, McIntosh TK, Gonzales MF, Weinstein PR, Faden AI (1988) Levels of endogenous opioids and effects of an opiate antagonist during regional cerebral ischemia in rats. J Pharmacol Exp Ther 247:1248-1254.

Arias RL, Sung ML, Vasylyev D, Zhang MY, Albinson K, Kubek K, Kagan N, Beyer C, Lin Q, Dwyer JM, Zaleska MM, Bowlby MR, Dunlop J, Monaghan M (2008) Amiloride is neuroprotective in an MPTP model of Parkinson's disease. Neurobiol Dis 31:334-341.

Askwith CC, Cheng C, Ikuma M, Benson C, Price MP, Welsh MJ (2000) Neuropeptide FF and FMRFamide potentiate acid-evoked currents from sensory neurons and proton-gated DEG/ENaC channels. Neuron 26:133-141.

Askwith CC, Wemmie JA, Price MP, Rokhlina T, Welsh MJ (2004) Acidsensing ion channel 2 (ASIC2) modulates ASIC1 $\mathrm{H}+$-activated currents in hippocampal neurons. J Biol Chem 279:18296-18305.

Babini E, Paukert M, Geisler HS, Grunder S (2002) Alternative splicing and interaction with di- and polyvalent cations control the dynamic range of acid-sensing ion channel 1 (ASIC1). J Biol Chem 277:41597-41603.

Bässler EL, Ngo-Anh TJ, Geisler HS, Ruppersberg JP, Gründer S (2001) Molecular and functional characterization of acid-sensing ion channel (ASIC) 1b. J Biol Chem 276:33782-33787.

Benson CJ, Xie J, Wemmie JA, Price MP, Henss JM, Welsh MJ, Snyder PM (2002) Heteromultimers of DEG/ENaC subunits form $\mathrm{H}+$-gated channels in mouse sensory neurons. Proc Natl Acad Sci U S A 99:2338-2343.
Caudle RM, Dubner R (1998) Ifenprodil blocks the excitatory effects of the opioid peptide dynorphin 1-17 on NMDA receptor-mediated currents in the CA3 region of the guinea pig hippocampus. Neuropeptides 32:87-95. Caudle RM, Mannes AJ (2000) Dynorphin: friend or foe? Pain 87:235-239.

Chen L, Gu Y, Huang LY (1995) The opioid peptide dynorphin directly blocks NMDA receptor channels in the rat. J Physiol 482:575-581.

Chen X, Kalbacher H, Gründer S (2005) The tarantula toxin psalmotoxin 1 inhibits acid-sensing ion channel (ASIC) la by increasing its apparent H+ affinity. J Gen Physiol 126:71-79.

Chen X, Kalbacher H, Gründer S (2006a) Interaction of acid-sensing ion channel (ASIC) 1 with the tarantula toxin psalmotoxin 1 is state dependent. J Gen Physiol 127:267-276.

Chen X, Paukert M, Kadurin I, Pusch M, Gründer S (2006b) Strong modulation by RFamide neuropeptides of the ASIC1b/3 heteromer in competition with extracellular calcium. Neuropharmacology 50:964-974.

Clausen T, Khaldi A, Zauner A, Reinert M, Doppenberg E, Menzel M, Soukup J, Alves OL, Bullock MR (2005) Cerebral acid-base homeostasis after severe traumatic brain injury. J Neurosurg 103:597-607.

Cone RI, Weber E, Barchas JD, Goldstein A (1983) Regional distribution of dynorphin and neo-endorphin peptides in rat brain, spinal cord, and pituitary. J Neurosci 3:2146-2152.

Coryell MW, Wunsch AM, Haenfler JM, Allen JE, McBride JL, Davidson BL, Wemmie JA (2008) Restoring acid-sensing ion channel-1a in the amygdala of knock-out mice rescues fear memory but not unconditioned fear responses. J Neurosci 28:13738-13741.

Deval E, Baron A, Lingueglia E, Mazarguil H, Zajac JM, Lazdunski M (2003) Effects of neuropeptide SF and related peptides on acid sensing ion channel 3 and sensory neuron excitability. Neuropharmacology 44:662-671.

Drummond HA, Jernigan NL, Grifoni SC (2008) Sensing tension: epithelial sodium channel/acid-sensing ion channel proteins in cardiovascular homeostasis. Hypertension 51:1265-1271.

Duan B, Wu LJ, Yu YQ, Ding Y, Jing L, Xu L, Chen J, Xu TL (2007) Upregulation of acid-sensing ion channel ASICla in spinal dorsal horn neurons contributes to inflammatory pain hypersensitivity. J Neurosci 27:11139-11148.

Escoubas P, De Weille JR, Lecoq A, Diochot S, Waldmann R, Champigny G, Moinier D, Ménez A, Lazdunski M (2000) Isolation of a tarantula toxin specific for a class of proton-gated $\mathrm{Na}+$ channels. J Biol Chem 275:25116-25121.

Ettaiche M, Deval E, Cougnon M, Lazdunski M, Voilley N (2006) Silencing acid-sensing ion channel 1a alters cone-mediated retinal function. J Neurosci 26:5800-5809.

Faden AI (1996) Neurotoxic versus neuroprotective actions of endogenous opioid peptides: implications for treatment of CNS injury. NIDA Res Monogr 163:318-330.

Fischli W, Goldstein A, Hunkapiller MW, Hood LE (1982) Isolation and amino acid sequence analysis of a 4,000-dalton dynorphin from porcine pituitary. Proc Natl Acad Sci U S A 79:5435-5437.

Friese MA, Craner MJ, Etzensperger R, Vergo S, Wemmie JA, Welsh MJ, Vincent A, Fugger L (2007) Acid-sensing ion channel-1 contributes to axonal degeneration in autoimmune inflammation of the central nervous system. Nat Med 13:1483-1489.

Gao J, Duan B, Wang DG, Deng XH, Zhang GY, Xu L, Xu TL (2005) Coupling between NMDA receptor and acid-sensing ion channel contributes to ischemic neuronal death. Neuron 48:635-646.

Goldstein A, Ghazarossian VE (1980) Immunoreactive dynorphin in pituitary and brain. Proc Natl Acad Sci U S A 77:6207-6210.

Harris RJ, Richards PG, Symon L, Habib AH, Rosenstein J (1987) pH, K+, and $\mathrm{PO} 2$ of the extracellular space during ischaemia of primate cerebral cortex. J Cereb Blood Flow Metab 7:599-604.

Hauser KF, Aldrich JV, Anderson KJ, Bakalkin G, Christie MJ, Hall ED, Knapp PE, Scheff SW, Singh IN, Vissel B, Woods AS, Yakovleva T, Shippenberg TS (2005) Pathobiology of dynorphins in trauma and disease. Front Biosci 10:216-235.

Höllt V (1986) Opioid peptide processing and receptor selectivity. Annu Rev Pharmacol Toxicol 26:59-77.

Kuzmin A, Madjid N, Terenius L, Ogren SO, Bakalkin G (2006) Big dynorphin, a prodynorphin-derived peptide produces NMDA receptormediated effects on memory, anxiolytic-like and locomotor behavior in mice. Neuropsychopharmacology 31:1928-1937.

Lai J, Luo MC, Chen Q, Ma S, Gardell LR, Ossipov MH, Porreca F (2006) 
Dynorphin A activates bradykinin receptors to maintain neuropathic pain. Nat Neurosci 9:1534-1540.

Lai J, Luo MC, Chen Q, Porreca F (2008) Pronociceptive actions of dynorphin via bradykinin receptors. Neurosci Lett 437:175-179.

Lai SL, Gu Y, Huang LY (1998) Dynorphin uses a non-opioid mechanism to potentiate $\mathrm{N}$-methyl-D-aspartate currents in single rat periaqueductal gray neurons. Neurosci Lett 247:115-118.

Massardier D, Hunt PF (1989) A direct non-opiate interaction of dynorphin-(1-13) with the N-methyl-D-aspartate (NMDA) receptor. Eur J Pharmacol 170:125-126.

Mazzuca M, Heurteaux C, Alloui A, Diochot S, Baron A, Voilley N, Blondeau N, Escoubas P, Gélot A, Cupo A, Zimmer A, Zimmer AM, Eschalier A, Lazdunski M (2007) A tarantula peptide against pain via ASICla channels and opioid mechanisms. Nat Neurosci 10:943-945.

McIntosh TK, Hayes RL, DeWitt DS, Agura V, Faden AI (1987) Endogenous opioids may mediate secondary damage after experimental brain injury. Am J Physiol 253:E565-E574.

Merg F, Filliol D, Usynin I, Bazov I, Bark N, Hurd YL, Yakovleva T, Kieffer BL, Bakalkin G (2006) Big dynorphin as a putative endogenous ligand for the kappa-opioid receptor. J Neurochem 97:292-301.

Pignataro G, Simon RP, Xiong ZG (2007) Prolonged activation of ASIC1a and the time window for neuroprotection in cerebral ischaemia. Brain 130:151-158.

Salinas M, Rash LD, Baron A, Lambeau G, Escoubas P, Lazdunski M (2006) The receptor site of the spider toxin PcTx1 on the proton-gated cation channel ASIC1a. J Physiol 570:339-354.

Schwarzer C (2009) 30 years of dynorphins-new insights on their functions in neuropsychiatric diseases. Pharmacol Ther 123:353-370.

Sherwood T, Franke R, Conneely S, Joyner J, Arumugan P, Askwith C (2009) Identification of protein domains that control proton and calcium sensitivity of ASIC1a. J Biol Chem 284:27899-27907.

Sherwood TW, Askwith CC (2008) Endogenous arginine-phenylalanineamide-related peptides alter steady-state desensitization of ASIC1a. J Biol Chem 283:1818-1830.

Siesjö BK, Katsura KI, Kristián T, Li PA, Siesjö P (1996) Molecular mechanisms of acidosis-mediated damage. Acta Neurochir Suppl 66:8-14.

Tan-No K, Cebers G, Yakovleva T, Hoon Goh B, Gileva I, Reznikov K, Aguilar-Santelises M, Hauser KF, Terenius L, Bakalkin G (2001) Cytotoxic effects of dynorphins through nonopioid intracellular mechanisms. Exp Cell Res 269:54-63.

Tan-No K, Esashi A, Nakagawasai O, Niijima F, Tadano T, Sakurada C, Sakurada T, Bakalkin G, Terenius L, Kisara K (2002) Intrathecally administered big dynorphin, a prodynorphin-derived peptide, produces nociceptive behavior through an N-methyl-D-aspartate receptor mechanism. Brain Res 952:7-14.

Ugawa S, Ueda T, Yamamura H, Shimada S (2005) In situ hybridization evidence for the coexistence of ASIC and TRPV 1 within rat single sensory neurons. Brain Res Mol Brain Res 136:125-133.

von Hanwehr R, Smith ML, Siesjö BK (1986) Extra- and intracellular pH during near-complete forebrain ischemia in the rat. J Neurochem 46:331-339.

Waldmann R, Champigny G, Bassilana F, Heurteaux C, Lazdunski M (1997) A proton-gated cation channel involved in acid-sensing. Nature 386:173-177.

Walker JM, Moises HC, Coy DH, Baldrighi G, Akil H (1982) Nonopiate effects of dynorphin and des-Tyr-dynorphin. Science 218:1136-1138.

Wemmie JA, Askwith CC, Lamani E, Cassell MD, Freeman JH Jr, Welsh MJ (2003) Acid-sensing ion channel 1 is localized in brain regions with high synaptic density and contributes to fear conditioning. J Neurosci 23: 5496-5502.

Wemmie JA, Price MP, Welsh MJ (2006) Acid-sensing ion channels: advances, questions and therapeutic opportunities. Trends Neurosci 29: 578-586.

Winkler T, Sharma HS, Gordh T, Badgaiyan RD, Stålberg E, Westman J (2002) Topical application of dynorphin A (1-17) antiserum attenuates trauma induced alterations in spinal cord evoked potentials, microvascular permeability disturbances, edema formation and cell injury: an experimental study in the rat using electrophysiological and morphological approaches. Amino Acids 23:273-281.

Wollemann M, Benyhe S (2004) Non-opioid actions of opioid peptides. Life Sci 75:257-270.

Wong HK, Bauer PO, Kurosawa M, Goswami A, Washizu C, Machida Y, Tosaki A, Yamada M, Knöpfel T, Nakamura T, Nukina N (2008) Blocking acid-sensing ion channel 1 alleviates Huntington's disease pathology via an ubiquitin-proteasome system-dependent mechanism. Hum Mol Genet 17:3223-3235.

Woods AS, Kaminski R, Oz M, Wang Y, Hauser K, Goody R, Wang HY, Jackson SN, Zeitz P, Zeitz KP, Zolkowska D, Schepers R, Nold M, Danielson J, Gräslund A, Vukojevic V, Bakalkin G, Basbaum A, Shippenberg T (2006) Decoy peptides that bind dynorphin noncovalently prevent NMDA receptor-mediated neurotoxicity. J Proteome Res 5:1017-1023.

Xiong ZG, Zhu XM, Chu XP, Minami M, Hey J, Wei WL, MacDonald JF, Wemmie JA, Price MP, Welsh MJ, Simon RP (2004) Neuroprotection in ischemia: blocking calcium-permeable acid-sensing ion channels. Cell 118:687-698.

Xiong ZG, Chu XP, Simon RP (2007) Acid sensing ion channels-novel therapeutic targets for ischemic brain injury. Front Biosci 12:1376-1386.

Zhang Z, Chen TY, Kirsch JR, Toung TJ, Traystman RJ, Koehler RC, Hurn PD, Bhardwaj A (2003) Kappa-opioid receptor selectivity for ischemic neuroprotection with BRL 52537 in rats. Anesth Analg 97:1776-1783.

Ziemann AE, Schnizler MK, Albert GW, Severson MA, Howard MA 3rd, Welsh MJ, Wemmie JA (2008) Seizure termination by acidosis depends on ASICla. Nat Neurosci 11:816-822. 